
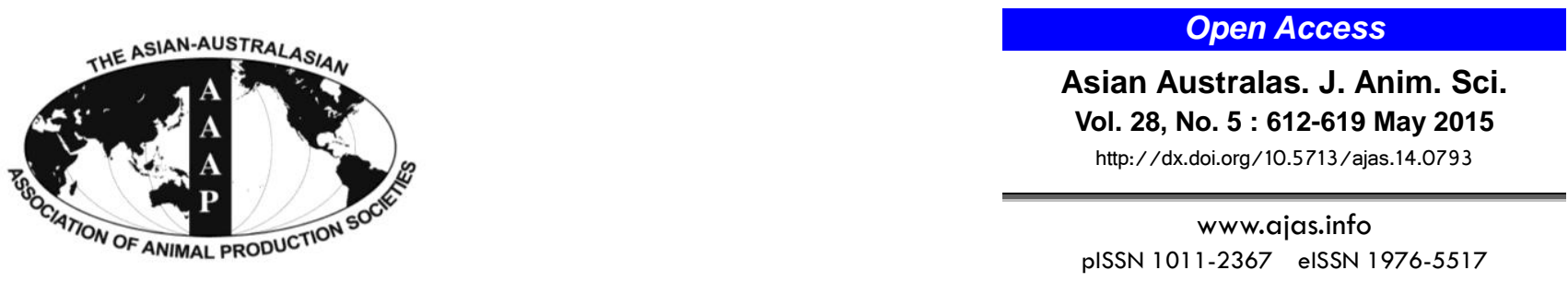

\title{
Animal Performance and Carcass Characteristics of Bulls (1/2 Purunã vs $1 / 2$ Canchim) Slaughtered at 16 and 22 Months Old, and Three Different Weights
}

\author{
Ivanor Nunes do Prado*, Carlos Emanuel Eiras, Carlos Alberto Fugita ${ }^{1}$, Rodrigo Augusto Cortêz Passetti, \\ Mariana Garcia Ornaghi, Dayane Cristina Rivaroli, Adriana Aparecida Pinto ${ }^{2}$, and José Luiz Moletta ${ }^{3}$ \\ Department of Animal Science, State University of Maringá, Maringá, PR 87020-900, Brazil
}

\begin{abstract}
Current study aimed to evaluate the performance of bulls (1/2 Purunã vs $1 / 2$ Canchim) slaughtered at two ages and three different weights. One hundred and thirteen bulls were divided into two slaughter ages (16 and 22 months) and three different slaughter weights (light, $422 \mathrm{~kg}$; medium, $470 \mathrm{~kg}$; and heavy, $550 \mathrm{~kg}$ ). The body weight was higher for bulls slaughtered at 16 months. Daily gain, carcass weight and dressing were higher for bulls slaughtered at 16 months. Feed intake was higher for bulls slaughtered at 22 months although feed efficiency was better for bulls slaughtered at 16 months. Carcass characteristics were better for bulls slaughtered at 16 months. The percentages of muscle, fat and bone and meat characteristics were similar between two slaughter ages. Feed intake and animal performance was lower for lighter animals. Feed conversion and carcass dressing were similar in the three slaughter weights. Muscle percentage was higher for heavier animals but fat and bone percentages were lower. Slaughter weight had no effect on meat characteristics. (Key Words: Crossbreeding, Feedlot, Feed Intake, Slaughter Age)
\end{abstract}

\section{INTRODUCTION}

In Brazil $90 \%$ of beef production is generally carried out with animals from Zebu origin, finished in pasture system, castrated and slaughtered between 30 and 42 months of age (ANUALPEC, 2014). Meat quality from these animals is lower in comparison to that from animals of European origin and slaughtered at a younger age (Ito et al., 2010; Ito et al., 2012; Maggioni et al., 2012). Currently several tools are used to improve the beef meat quality, for example, crossbreeding between Zebu and European breeds, finishing non-castrated animals, slaughter of young animals

\footnotetext{
* Corresponding Author: Ivanor N. Prado. Tel: +55-44-30118931, Fax: +55-44-3011-8977, E-mail: inprado@uem.br ${ }^{1}$ Departament of Agriculture, Goiáno Federal Institute, Cristalina, GO 73850-000, Brazil.

2 Department of Veterinary Medicine, State University of Maringá, Umuarama, PR 87020-900, Brazil.

${ }^{3}$ Department of Animal Science, Agronomic Institute of Paraná, Ponta Grossa, PR 84001-970, Brazil.

Submitted Oct. 13, 2014; Revised Nov. 25, 2014; Accepted Dec. 13, 2014
}

and finishing the animals in a feedlot system (Abrahão et al., 2005; Maggioni et al., 2009).

On the other hand, the beef market in Brazil requires a carcass between 225 to $250 \mathrm{~kg}$ with minimum $3 \mathrm{~mm}$ fat thickness (FAT) and good conformation. In fact, the production of young bulls has been the subject of interest from researchers and producers. Ito et al. (2010) and Ito et al. (2012) showed that bulls finished at 14 months are more efficient when compared to bulls slaughtered at 24 months of age. There are important differences in carcass characteristics between the two categories when they are slaughtered with similar carcass weight, with the exception of carcass yield which is higher in younger animals (Rotta et al., 2009). Young animals are more valued for their meat quality (Ito et al., 2010; Kuss et al., 2010). The slaughter of animals with high weight determines a change in animal performance, feed efficiency and carcass characteristics (Rotta et al., 2009). Thus, the slaughter weight is highly important in feedlots due to costs and final product quality. However, a finishing system that enables the animal to gain around 1.4 to $1.6 \mathrm{~kg} / \mathrm{d}$ is required to slaughter animals with 
high weight. Thus, feedlot systems are an alternative, albeit an expensive one (Dian et al., 2010; Silva et al., 2010). Crossbred animals have greatest potential for weight gain in feedlots (Prado et al., 2008a; Rotta et al., 2009; Prado et al., 2011).

The current analysis evaluates the performance of young bulls (1/2 Purunã vs $1 / 2$ Canchim) slaughtered at 16 or 22 months old, with three different body weights (BW) (light, $422 \mathrm{~kg}$; medium, 470; heavy, $520 \mathrm{~kg}$ ).

\section{MATERIALS AND METHODS}

\section{Animals, housing and diets}

The experiment was approved by the Department of Animal Science of the State University of Maringá (CIOMS/OMS, 1985) and was conducted at the Experimental Station of the Paraná Agronomic Institute (IAPAR) in Ponta Grossa, Paraná, Brazil.

One hundred and thirteen crossbred bulls $1 / 2$ Purunã vs 1/2 Canchim were used in a factorial design (two ages, 16 months old, M16 and 22 months old, M22) and three slaughter weights (light, 422; medium, 470; heavy, $550 \mathrm{~kg}$ ).

Calves in treatments M16 and M22 from birth to the age of 90 days were kept with cows grazing on winter pasture (Hemarthria altissima). After early weaning (90 days of age), the calves were kept on the same pasture with additional supplementation of concentrate $(1.5 \mathrm{~kg} / \mathrm{animal} /$ day of a mixture with $25 \%$ soybean meal $+73 \%$ ground corn $+2 \%$ mineral salt) during the winter period. Bulls in treatment M16 were fed in collective pens and transferred to individual feedlots on the 12th month of age where they remained for four months and at 16 months of age were slaughtered while bulls of M22 on 16th month of age were transferred to individual feedlots where they remained for another six months and at 22 months were slaughtered. In M16 treatment, 22 bulls were slaughtered with light BW; 20 with medium BW; 20 with heavy BW. In M22 treatment, 18 bulls were slaughtered with light $\mathrm{BW}$; 16 with medium $\mathrm{BW}$; 17 with heavy BW.

Bulls were weighted and then distributed into six treatments. They were allocated into individual pens $\left(8 \mathrm{~m}^{2}\right.$ for each animal) within a feedlot system. The bulls' BW was recorded monthly whilst intake of concentrate and corn silage was recorded daily, until the end of the experiment when the bulls were slaughtered. All diets were formulated as iso-nitrogenous. The bulls were fed ad libitum twice a day (08:00 and 15:00 h) on concentrate and corn silage in separate troughs. The concentrate intake was fixed in $1.2 \%$ of BW and adjusted every 28 days. The diet formulation and quantity supplied were designed to provide a weight gain of $1.4 \mathrm{~kg} / \mathrm{d}$, according to NRC (2000) estimates.

\section{Nutrients and diets analyses}

Analytical dry matter (DM) content of oven-dried samples was determined by drying at $135^{\circ} \mathrm{C}$ for $3 \mathrm{~h}$ by method 930.15 (AOAC, 1998). The organic matter content was calculated as the difference between DM content and ash content. Ash was determined by using combustion at $550^{\circ} \mathrm{C}$ for $5 \mathrm{~h}$. Nitrogen content in the samples was determined by method 976.05 (AOAC, 1998). The neutral detergent fiber (NDF) and acid detergent fiber contents were determined using the methods described by Van Soest et al. (1991) with heat stable alpha-amylase for solubilization of the amylaceous compounds (Mertens, 2002) and sodium sulfite in NDF procedure. Contents are expressed inclusive of residual ash. Samples were analyzed at the Laboratory of Feed Analyses and Animal Nutrition of the State University of Maringá (Table 1).

\section{Performance, feed intake and feed efficiency}

To evaluate animal performance, bulls were weighed after fasting from solid food for a period of 16 hours at the beginning of the experimental period and thereafter at 21day intervals. The daily feed intake was estimated by the difference between supplied feed and refusals in the trough. Refused feed represented 5\% of the total. During the collection period, samples of the supplied feed and refused feed were collected and a representative composite sample was drafted per animal in each diet for analysis. Dry matter conversion (DMC) was calculated by the following equations $\mathrm{DMC}=($ dry matter intake $[\mathrm{DMI}] /$ daily average gain).

\section{Carcass characteristics measurements}

Bulls were slaughtered according to industrial practices in Brazil at a commercial slaughterhouse $10 \mathrm{~km}$ from the

Table 1. Chemical composition (g/kg DM) of ingredients and diet

\begin{tabular}{llllllll}
\hline Items & DM & CP & Ash & OM & NDF & ADF & EE \\
\hline Ingredients & & & & & & & \\
$\quad$ Corn silage & 520 & 61.6 & 35.0 & 965 & 574 & 267 & 35.0 \\
$\quad$ Corn grain & 350 & 98.0 & 14.6 & 985 & 108 & 33.0 & 40.0 \\
$\quad$ Soybean meal & 120 & 51.8 & 6.90 & 931 & 103 & 70.0 & 16.5 \\
$\quad$ Mineral salt & 100 & & 99.0 & & & & \\
Diet & 494 & 128 & 41.6 & 958.4 & 348 & 158 & 34.2 \\
\hline
\end{tabular}

DM, dry matter; CP, crude protein; OM, organic matter; NDF, neutral detergent fiber; ADF, acid detergent fiber; EE, ether extract. 
Ponta Grossa Research Farm.

Carcasses were chilled for $24 \mathrm{~h}$ at $4^{\circ} \mathrm{C}$. After chilling, the right side of the carcass was used to determine quantitative characteristics. Hot carcass weight $(\mathrm{HCW})$ was determined soon after slaughter and prior to carcass chilling. Hot carcass dressing (HCD) is the percentage of individual animal dressing and is defined by ratio HCW:BW. Carcass length (CAL) was measured from the skull board to the pubic bone on the anterior side of the first rib. Leg length (LEL) was evaluated with a wooden compass with metallic edges that measured the distance from the anterior border of the pubis bone to a middle point on the tarsus bone.

Cushion thickness (CUT) was determined with a wooden compass with metallic edges that measured the distance between the lateral face and the median at the superior part of the cushion. The cushion is the flat muscle (Biceps femoris). Carcass conformation (CONF) was determined after excluding FAT where the highest value indicated the best conformation. The CONF may be superior, very good, good, regular, poor or inferior; ratings may also be reported as plus, average and minus.

Muscle, fat and bone were physically separated from the Longissimus muscle (LM) section, which corresponded to the 10th, 11th, and 12th ribs, and individually weighed according to Hankins and Howe (1946), as follows: \% $\mathrm{M}=$ $6.292+0.910 \mathrm{X}_{1}, \% \mathrm{~F}=1.526+0.913 \mathrm{X}_{2}$, and $\% \mathrm{~B}=$ $2.117+0.860 \mathrm{X}_{3}$, in which $\mathrm{X}_{1}, \mathrm{X}_{2}$, and $\mathrm{X}_{3}$ represent muscle (MP), fat (FP), and bone (BP) percentages, respectively.

\section{Meat characteristics measurements}

Longissimus muscle area (LMA) was measured on the right side of the carcass, after a cross-section cut was made between the 12th and 13th ribs by a compensating planimeter that measured the areas of irregular shaped objects. LMA/100 kg carcass (LMC) is defined by the ratio LMA:HCW, multiplied by 100 . The FAT was measured by a caliper, between the 12th and 13th ribs, over the LM, with a three-point measure average. Marbling was measured in LM between the 12th and 13th ribs, following scores used in Brazilian slaughterhouse (18 to 16 , abundant; 15 to 13 , moderate; 12 to 10 , mean; 9 to 7 , small; 6 to 4 , light; 3 to 1 , traces). Texture (TEX) was determined by fascicle size (muscular "grain" size) and evaluated subjectively on a point scale (very fine, 5 ; fine, 4 ; slightly, 3; coarse, 2; very coarse, 1).

Coloration was evaluated according to a point scale 30 minutes after a cross-sectional cut was made on the LM between the 12th and 13th ribs (cherry red, 5; red, 4; slightly red, 3; dark red, 2; dark, 1). Color was analyzed after a 24-hour carcass chilling in the LM.

\section{Statistics analyses}

Bulls were distributed in a complete randomized design by a $2 \times 3$ factorial scheme, comprising two slaughter ages (16 and 22 months) and three slaughter weights (light, 422 $\mathrm{kg}$; medium, $470 \mathrm{~kg}$; heavy, $520 \mathrm{~kg}$ ). Results were submitted to analysis of variance and means were compared by Tukey's test using SAS (2004), according to the following model: $\mathrm{Y}_{\mathrm{ij}}=\mu+\mathrm{S}_{\mathrm{i}}+\mathrm{P}_{\mathrm{j}}+\mathrm{S}_{\mathrm{i}} \times \mathrm{P}_{\mathrm{j}}+\mathrm{e}_{\mathrm{ij}}$; where $\mathrm{Y}_{\mathrm{ij}}=$ observation of the animal undergoing treatment $\mathrm{i}$ and $\mathrm{j} ; \mu=$ constant overall; $S_{i}=$ effect of the finishing system $i ; i=1$ or $2 ; P_{j}=$ effect of slaughter weight $j ; j=1,2$, or $3, S_{i} \times P_{j}=$ interaction termination system $\times$ slaughter weight and $\mathrm{e}_{\mathrm{ij}}=$ random error associated with each observation $\mathrm{Y}_{\mathrm{ij}}$.

\section{RESULTS AND DISCUSSION}

Data analysis found no interaction between slaughter age (16, M16 or 22, M22 months) and slaughter weight (light, medium or heavy), dates were presented and discussed as principal effects.

\section{Age effect}

Feed intake (dry matter intake $[\mathrm{DMI}]$, crude protein intake [CPI], neutral detergent fiber intake [NDFI]) $\mathrm{kg} / \mathrm{animal} / \mathrm{d}$ was similar ( $\mathrm{p}>0.05$ ) for bulls from M16 and M22 treatments (Table 2). Average of DMI, CPI, and NDFI were $10.2,1.22$, and $3.55 \mathrm{~kg} / \mathrm{animal} / \mathrm{d}$. DMI and CPI were above the rates observed for bulls finished in feedlot. The DMI and CPI were generally between 6 to $8 \mathrm{~kg} / \mathrm{animal} / \mathrm{d}$ and 0.9 to $1.1 \mathrm{~kg} / \mathrm{animal} / \mathrm{d}$ for bulls finished in feedlot and fed on adequate level of protein and energy for obtained all the requirements for gain of $1.4 \mathrm{~kg} / \mathrm{d}$ (NRC, 2000). High DMI and CPI could be explained by young bulls requiring high protein and energy during puberty (NRC, 2000). The DMI and NDFI in relation to the BW were similar $(\mathrm{p}>0.05)$ between bulls from M16 and M22 treatments. DMI and NDFI averages were $2.75 \%$ and $0.96 \%$ of BW. The DMI in relation to $\mathrm{BW}$ is generally between $2.0 \%$ and $2.5 \%$ of $\mathrm{BW}$ (Prado et al., 2000; Maggioni et al., 2009; Pinto et al., 2009). High DMI could be explained by diet quality, high average daily gain (ADG), animal age and animal requirements and low NDFI in the diet. Feed intake is actually controlled by NDFI (Forbes, 1988). According to Mertens (1994) and Maggioni et al. (2009), NDFI below $1.2 \%$ of BW does not interfere in DMI. The NDFI in current analysis was $0.96 \%$ of BW.

The DMC $(\mathrm{kg} \mathrm{DM} / \mathrm{kg} \mathrm{BW})$ was better $(\mathrm{p}<0.01)$ for M16 bulls when compared to M22 treatment ones. This was likely due to the bulls from M16 treatment being younger than those from M22 treatment and younger animals have better feed efficiency (Hocquette et al., 2007). Furthermore, bulls from M16 treatment had greater ADG. Cattle which exhibit high weight gain have a better feed efficiency since there is a positive correlation between weight gain and feed efficiency (Hocquette et al., 2007). 
Table 2. Feed intake, animal performance and carcass characteristics from crossbred bulls (1/2 Purunã vs $1 / 2$ Canchin) slaughtered at 16 or 22 months

\begin{tabular}{|c|c|c|c|c|}
\hline \multirow{2}{*}{ Parameters } & \multicolumn{2}{|c|}{ Age } & \multirow{2}{*}{ SEM } & \multirow{2}{*}{ p-value } \\
\hline & M16 & M22 & & \\
\hline \multicolumn{5}{|l|}{ Feed intake and efficiency } \\
\hline Dry matter $(\mathrm{kg} / \mathrm{d})$ & 9.98 & 10.3 & 0.23 & 0.35 \\
\hline Dry matter (\%/BW) & 2.73 & 2.76 & 0.08 & 0.32 \\
\hline Crude protein $(\mathrm{kg} / \mathrm{d})$ & 1.20 & 1.24 & 0.05 & 0.72 \\
\hline $\begin{array}{l}\text { Neutral detergent fiber } \\
(\mathrm{kg} / \mathrm{d})\end{array}$ & 3.49 & 3.61 & 0.16 & 0.26 \\
\hline $\begin{array}{l}\text { Neutral detergent fiber } \\
(\% / \mathrm{BW})\end{array}$ & 0.96 & 0.97 & 0.06 & 0.65 \\
\hline Dry matter conversion & 5.63 & 8.64 & 0.24 & 0.01 \\
\hline \multicolumn{5}{|l|}{ Animal performance } \\
\hline Initial weight (kg) & 259 & 282 & 5.11 & 0.06 \\
\hline Final weight (kg) & 472 & 468 & 3.00 & 0.12 \\
\hline Average daily gain (kg) & 1.77 & 1.03 & 0.04 & 0.02 \\
\hline \multicolumn{5}{|l|}{ Carcass characteristics } \\
\hline Hot carcass weight $(\mathrm{kg})$ & 259 & 251 & 2.16 & 0.06 \\
\hline Hot dressing carcass (\%) & 55.0 & 53.7 & 0.38 & 0.06 \\
\hline Carcass length $(\mathrm{cm})$ & 128 & 131 & 0.62 & 0.02 \\
\hline Leg length $(\mathrm{cm})$ & 67.5 & 70.2 & 0.32 & 0.01 \\
\hline Cushion thickness $(\mathrm{cm})$ & 26.0 & 26.3 & 0.20 & 0.64 \\
\hline Conformation, points & 14.1 & 13.5 & 0.23 & 0.32 \\
\hline Muscle (\%) & 60.5 & 61.4 & 1.25 & 0.35 \\
\hline Fat $(\%)$ & 25.0 & 23.3 & 1.15 & 0.41 \\
\hline Bone $(\%)$ & 14.5 & 15.3 & 0.20 & 0.26 \\
\hline \multicolumn{5}{|l|}{ Meat characteristics } \\
\hline Muscle Longissimus $\left(\mathrm{cm}^{2}\right)$ & 78.6 & 72.2 & 1.10 & 0.01 \\
\hline $\begin{array}{l}\text { Muscle Longissimus } \\
\quad\left(\mathrm{cm}^{2} / \% \mathrm{BW}\right)\end{array}$ & 27.6 & 27.0 & 0.35 & 0.24 \\
\hline Fat thickness $(\mathrm{cm})$ & 4.14 & 4.02 & 0.18 & 0.32 \\
\hline Color, points & 3.94 & 3.72 & 0.11 & 0.31 \\
\hline Marbling, points & 5.05 & 5.90 & 0.25 & 0.03 \\
\hline Texture, points & 4.67 & 4.45 & 0.15 & 0.42 \\
\hline
\end{tabular}

SEM, standard error mean; BW, body weight.

The initial live weight (ILW) was not similar $(\mathrm{p}<0.05)$ between bulls from M16 and M22 treatments when the light bulls were slaughtered (Table 2).

Lower ILW in bulls from M16 treatment was determined by younger age at the start of the feedlot period. Bulls from M16 treatment started in feedlot 12 months after birth while bulls from M22 treatment began in the feedlot at 16 months old. Although the ages were different, the difference between the bulls from M16 and M22 treatments was only $23 \mathrm{~kg}$. In fact, the difference was small because bulls in M16 were kept in a collective feedlot for two months before the start of the experiment and were fed on a diet with high energy and protein density when compared to bulls from M22 treatment. The bulls from M22 treatment were kept on a pasture system of Hermathria altissima prior to the experiment.
The final live weight (FLW) was similar $(p>0.05)$ for bulls from M16 and M22 treatments although ILW was higher in bulls from M22 treatments. Whereas bulls from M16 treatment were kept in feedlot for 120 days, the bulls from M22 treatment were kept in feedlot for 180 days. Therefore, similar FLW was due to a longer feedlot period collective to bulls from M16 treatment prior to the start of the experimental period.

Bulls from M16 treatment had greater $(\mathrm{p}<0.01)$ ADG than bulls from M22 treatment (Table 2) regardless of weight at slaughter. High slaughter ADG rate in bulls from M16 treatment may be due to longer feedlot period and also to lower age when compared to bulls from M22 treatment. As a rule, young bulls have higher ADG when compared to older bulls (López-Campos et al., 2012). Higher ADG in young bulls is generally due to the greater muscle deposition during the puberty phase when compared to old bulls which would be depositing more adipose tissue. The muscle deposition in puberty phase is determined by hormone activity such as growth hormone (Lunstra et al., 1978; Lee et al., 1990).

Although FLW was similar in bulls at different slaughter ages, the HCW was greater $(\mathrm{p}<0.05)$ in bulls from M16 treatment (Table 2). High HCW in M16 treatment bulls is due to the greater carcass dressing for the animals.

The HCD was higher $(\mathrm{p}<0.05)$ in bulls from M16 treatment (Table 2). Higher HCD in bulls from M16 treatment may be explained by their lower slaughter age (16 months) in comparison to the slaughter age of bulls from M22 (22 months). Young bulls show high HCD caused by frame, rumen fill, CONF and feedlot period (Ito et al., 2010; Arboitte et al., 2012).

The CALs and LELs were higher $(\mathrm{p}<0.01)$ for bulls from M22 treatment M22 than for bulls from M16 treatment (Table 2). This may be related to the animals' greater age and consequently greater body development. Genetics and nutrition have a smaller influence on these traits than does the animals age (Rotta et al., 2009).

Slaughter age had no influence $(p>0.05)$ on CUT and CONF (Table 2). According to the scale of points used for carcass classification, the average scores assigned ranks as good quality carcass which may be explained by slaughter age, weight and genetic quality of the animals. In general, carcasses from crossbred animals (Zebu and European) have good conformation carcass (Prado et al., 2008a, b).

The muscle, fat and bone percentages were similar ( $\mathrm{p}>$ 0.05 ) for bulls from two different ages at slaughter (Table 2). The muscle, fat and bone percentages were $61 \%, 24 \%$, and $15 \%$, respectively. Crossbred bulls finished in feedlot and fed on high protein and high energy density diets had between $55 \%$ and $65 \%$ muscle, $15 \%$ to $25 \%$ fat and $15 \%$ to $18 \%$ bone. Thus, rates in current study agree with rates reported in the literature (Rotta et al., 2009). 
The total LMA was greater $(\mathrm{p}<0.01)$ for bulls from M16 treatment (Table 2). However, Longissumus muscle related to BW was similar ( $p>0.05$ ) for bulls from M16 and M22. The same was reported for subcutaneous FAT. Rates for muscle Longissimus area are close to those in other studies with crossbred bulls finished in feedlot (Rotta et al., 2009). The subcutaneous FAT present on bulls in current study (4.1 $\mathrm{mm}$ ) is within the ideal rate range for beef cattle on the Brazilian market.

Age at slaughter had no effect ( $>0.05)$ on meat color and texture (Table 2). According to the rating scale used in current study, meat could be classified as red for color and thin for texture. In general, Zebu and European cross-breed bulls produce meat that meets the requirements of the beef market in Brazil. However, meat marbling was better $(p<0.05)$ for bulls slaughtered at 22 months of age (Table 2). The marbling fat is the last fat to be deposited on animal meat. Thus, older animals had a longer time for fat deposition. Since marbling is an important feature in meat quality, it is related to tenderness and juiciness. Bulls finished over a longer time on a diet with a high protein percentage and high energy density and slaughtered at an older age generally have higher fat marbling (Rotta et al., 2009).

\section{Slaughter weight effect}

Daily feed intake (DMI, CP, and NDF) was higher ( $>0.05$ ) in bulls slaughtered at medium and heavy weights compared to bulls slaughtered at light weight (Table 3). Crossbred bulls finished in feedlot with diets containing $12 \% \mathrm{CP}$ and $72 \%$ total nutrient digestible generally present a DMI ranging between 7 to $10 \mathrm{~kg} / \mathrm{d}$ (Maggioni et al., 2009; Dian et al., 2010).

DMI as a function of BW was similar $(\mathrm{p}>0.05)$ for bulls slaughtered with light, medium and heavy weights. DMI $(2.7 \% / \mathrm{BW})$ is above the recommended value for crossbred

Table 3. Feed intake, animal performance and carcass characteristics from crossbred bulls (1/2 Purunã vs $1 / 2$ Canchin) slaughtered at three different weights

\begin{tabular}{|c|c|c|c|c|c|}
\hline \multirow{2}{*}{ Parameters } & \multicolumn{3}{|c|}{ Slaughter weight } & \multirow{2}{*}{ SEM } & \multirow{2}{*}{ p-value } \\
\hline & Light & Medium & Heavy & & \\
\hline$\overline{\mathrm{N}}$ & 40 & 36 & 37 & & \\
\hline \multicolumn{6}{|l|}{ Feed intake and efficiency } \\
\hline Dry matter intake $(\mathrm{kg})$ & $9.16^{\mathrm{b}}$ & $10.54^{\mathrm{a}}$ & $10.74^{\mathrm{a}}$ & 0.27 & 0.04 \\
\hline Dry matter intake $(\% / \mathrm{BW})$ & 2.69 & 2.90 & 2.61 & 0.08 & 0.15 \\
\hline Crude protein intake $(\mathrm{kg})$ & $1.08^{\mathrm{b}}$ & $1.25^{\mathrm{a}}$ & $1.27^{\mathrm{a}}$ & 0.05 & 0.04 \\
\hline Neutral detergent fiber $(\mathrm{kg})$ & $3.14^{\mathrm{b}}$ & $3.64^{\mathrm{a}}$ & $3.64^{\mathrm{a}}$ & 0.01 & 0.01 \\
\hline Neutral detergent fiber (\%/BW) & 0.94 & 1.01 & 0.91 & 0.05 & 0.33 \\
\hline Dry matter conversion & 5.65 & 5.53 & 5.72 & 0.18 & 0.45 \\
\hline \multicolumn{6}{|l|}{ Animal performance } \\
\hline Initial live weight (kg) & $239.3^{\mathrm{c}}$ & $262.2^{\mathrm{b}}$ & $311.2^{\mathrm{a}}$ & 6.01 & 0.01 \\
\hline Final live weight $(\mathrm{kg})$ & $421.9^{c}$ & $469.3^{\mathrm{b}}$ & $519.0^{\mathrm{a}}$ & 4.25 & 0.01 \\
\hline Average daily gain $(\mathrm{kg})$ & $1.28^{\mathrm{b}}$ & $1.46^{\mathrm{a}}$ & $1.46^{\mathrm{a}}$ & 0.04 & 0.02 \\
\hline \multicolumn{6}{|l|}{ Carcass characteristics } \\
\hline Hot carcass weight $(\mathrm{kg})$ & $228.5^{\mathrm{c}}$ & $253.8^{\mathrm{b}}$ & $284.8^{\mathrm{a}}$ & 2.22 & 0.01 \\
\hline Hot carcass dressing (\%) & 54.1 & 54.0 & 54.9 & 0.36 & 0.31 \\
\hline Carcass length $(\mathrm{cm})$ & $126.4^{\mathrm{c}}$ & $127.9^{\mathrm{b}}$ & $130.1^{\mathrm{a}}$ & 0.59 & 0.01 \\
\hline Leg length $(\mathrm{cm})$ & $66.5^{\mathrm{b}}$ & $68.5^{\mathrm{a}}$ & $68.8^{\mathrm{a}}$ & 0.40 & 0.01 \\
\hline Cushion thickness $\left(\mathrm{cm}^{2}\right)$ & $25.2^{\mathrm{b}}$ & $25.9^{\mathrm{b}}$ & $27.2^{\mathrm{a}}$ & 0.24 & 0.01 \\
\hline Conformation, points & $12.5^{\mathrm{c}}$ & $13.9^{\mathrm{b}}$ & $15.2^{\mathrm{a}}$ & 0.24 & 0.01 \\
\hline Muscle (\%) & $58.9^{\mathrm{b}}$ & $59.9^{\mathrm{b}}$ & $65.0^{\mathrm{a}}$ & 1.52 & 0.03 \\
\hline Fat $(\%)$ & $26.5^{\mathrm{a}}$ & $25.4^{\mathrm{a}}$ & $21.2^{\mathrm{b}}$ & 1.51 & 0.02 \\
\hline Bone $(\%)$ & $15.2^{\mathrm{a}}$ & $15.3^{\mathrm{a}}$ & $14.6^{\mathrm{b}}$ & 0.25 & 0.01 \\
\hline \multicolumn{6}{|l|}{ Meat characteristics } \\
\hline Muscle Longissimus $\left(\mathrm{cm}^{2}\right)$ & $65.7^{\mathrm{c}}$ & $67.7^{\mathrm{b}}$ & $75.4^{\mathrm{a}}$ & 1.40 & 0.02 \\
\hline Muscle Longissimus $\left(\mathrm{cm}^{2} / \mathrm{BW}\right)$ & $28.8^{\mathrm{a}}$ & $26.6^{\mathrm{b}}$ & $25.6^{\mathrm{c}}$ & 0.73 & 0.03 \\
\hline Fat thickness (mm) & 3.92 & 3.88 & 4.45 & 0.24 & 0.41 \\
\hline Color, points & 3.79 & 3.83 & 3.89 & 0.13 & 0.29 \\
\hline Marbling, points & 5.65 & 5.38 & 5.40 & 0.31 & 0.31 \\
\hline Texture, points & 4.47 & 4.58 & 4.64 & 0.18 & 0.29 \\
\hline
\end{tabular}

SEM, standard error mean; BW, body weight.

${ }^{a, b, c}$ Means followed by different letters are different $(p<0.05)$. 
bulls finished in feedlot and fed on a high protein and density energy diet (NRC, 2000). The DMI is regulated by NDFI (Forbes, 1988; Mertens, 1994; Maggioni et al., 2009). In current study, NDFI was $0.96 \%$ of BW. The DMI is reduced when NDFI is above $1.2 \%$ of BW (Forbes, 1988; Mertens, 1994; Maggioni et al., 2009).

The DMC was similar ( $p>0.05)$ for bulls slaughtered at three different weights (Table 3 ). The mean DMC rate was $5.63 \mathrm{~kg}$ of DM for $1.0 \mathrm{~kg}$ of BW gain. Feed conversion was similar to that reported by Maggioni et al. (2009). The DMC in current research may be considered normal for young bulls finished in feedlot and fed on a diet with high energy density. In general, young bulls finished without food restriction have good feed conversion (Dian et al., 2010).

According to bulls' distribution in current experiment, ILW was lower in light bulls; intermediate in medium bulls and higher in heavy bulls (Table 3). Similarly, FLW was lower in light bulls, intermediate in medium bulls and higher in heavy bulls. Reported differences in ILW and FLW were due to the bulls' weight at the beginning of feedlot. In general, heavier bulls at the start of feedlot were also heavier at the end.

The ADG was lower $(\mathrm{p}<0.05)$ for light bulls than for medium and heavy ones (Table 3 ). However, there was no effect $(p>0.05)$ on ADG between bulls with medium and heavy weights (Table 3). Lowest ADG in light bulls may be due to their genetic potential because all the animals were of a similar age. The ADG was $1.40 \mathrm{~kg}$ and may be considered low for the animal category (young bulls fed on high protein and energy density, derived from cross-breeds Zebu and European). As a rule, bulls from this category have ADG between 1.6 and $2.0 \mathrm{~kg}$. Low ADG gain could be explained by the long feed lot period (120 days for bulls from M16 treatment and 180 days for bulls from M22 treatment). The ADG is reduced significantly with the feedlot time.

The HCW was greater $(\mathrm{p}<0.05)$ in heavy bulls when compared to medium and light weight ones (Table 3). Yet, HCW from bulls slaughtered with medium weight was greater $(\mathrm{p}<0.01)$ when compared to HCW from light bulls. The differences among treatments for $\mathrm{HCW}$ may be explained by different slaughter weights.

The HCD was similar ( $>0.05)$ among bulls from three slaughter weights (Table 3 ) with a $54.5 \%$ average. The HCD is close to rates reported by (Prado et al., 2008a, b; Rotta et al., 2009) in crossbred bulls and finished in similar feedlot conditions. The CAL, LEL, and CUT rates were greater $(p<0.01)$ in heavy bulls; intermediate in medium bulls and smaller in light bulls. Likewise, CONF was better $(\mathrm{p}<0.01)$ in heavy bulls, intermediate for medium bulls and lower in light bulls (Table 3). These physical characteristics are determined by weigh of animals at slaughter. Reported data in current study are normal for different laughter weight for the three animal categories.

Heavy weight bulls at slaughter have higher $(\mathrm{p}<0.05)$ muscle percentage when compared to light and medium weight bulls at slaughter. Better muscle capacity in comparison to bulls' medium and light weights at slaughter is representative by their respective frame. Animals of the same genetic group and maintained under the same rearing conditions may have distinct characteristics for animal individuality. A high proportion of muscle in the carcass, above $62 \%$, is explained by the age at slaughter and density protein on diets (12\%). According Berg and Walters (1983) the tissues compositions could be associated with animal growing and different stages of body formations. Pacheco et al. (2005) observed higher muscle percentage $(60.3 \%$ vs $66.5 \%$ ) on meat quality of young bulls slaughtered at 23 than 15 months old.

Fat and bone percentages were higher $(\mathrm{p}<0.05)$ for light and medium weight bulls at slaughter than for heavy bulls (Table 3). Light and medium bulls demonstrated a higher fat percentage in relation to heavy bulls. According to Ito et al. (2012) the animal weight could be related with the stages of tissue formations. Therefore, heavy bulls at slaughter were late in deposited fat tissues in relation to light and medium bulls at slaughter. Ito et al. (2010) observed higher fat percentage $(23.6 \%$ vs $20.0 \%)$ on LM of young bulls slaughtered at 18 and 24 months old. The bulls' bone percentage is below the rates observed in young cattle and crossbred feedlot (Dian et al., 2010). However, bone is only a small percentage at slaughter and in the cattle with a high weight gain. In fact, low bone percentage is desirable in carcass cattle.

The LMA was high $(\mathrm{p}<0.05)$ in heavy bulls, intermediate in medium bulls and small in light bulls at slaughter (Table 3). A greater LM may be due to the high carcass weight and great muscularity in heavy bulls. (Rotta et al., 2009; Maggioni et al., 2012) observed that increasing weight at slaughter increased LM. However, when LM per $100 \mathrm{~kg} \mathrm{BW}$ was assessed, the high $(\mathrm{p}<0.05)$ LM was observed for light bulls at slaughter, intermediate for medium bulls and low in heavy bulls at slaughter. The higher LM/100 kg BW observed in light cattle could be explained by increased deposition of muscle that occurred in lighter animals. According to the animals' physiological growth, muscle tissue is deposited before the adipose tissue, and therefore lighter animals have higher deposition of muscle, whereas higher fat deposition occurs in heavier animals.

The FAT, color, texture and marbling were not affected ( $>0.05$ ) by different weights at slaughter (Table 3). Reported rates for the three slaughter weights are in 
accordance with market requirements in Brazil. The meat was classified red for color, light for marbling and thin for texture, following scale used in current study.

\section{CONCLUSION}

In the current investigation bulls were slaughtered at two life stages; 16 and 22 months old, with three different BW; 422, 470, and $550 \mathrm{~kg}$. Results were different for the two bulls groups. With regard to the slaughter age, bulls slaughtered younger (16 months) showed higher animal performance, better feed efficiency and carcass yield. However, a lower age at slaughter had no negative effect on carcass and meat characteristics. Thus, younger age at slaughter (16 months) would have a better cost-benefit ratio due to a younger age at slaughter and lower production costs. On the other hand, bulls slaughtered at $470 \mathrm{~kg}$ or 550 $\mathrm{kg}$ BW showed better performance when compared to bulls slaughtered at $422 \mathrm{~kg} \mathrm{BW}$. Carcass characteristics were better for heavier bulls, although meat characteristics were similar for all three animal groups. Thus, the lowest weight at slaughter had no negative influence on the meat's qualitative aspects. Consequently, the best slaughter weight for Bos taurus and Bos indicus crossbred bulls is between 470 and $550 \mathrm{~kg}$.

\section{REFERENCES}

Abrahão, J. J. S., I. N. Prado, D. Perotto, and J. L. Moletta. 2005. Effect of replacing corn by increasing levels of cassava starch by-products on carcass characteristics and meat for young bulls. R. Bras. Zootec. 34:1640-1650.

ANUALPEC. 2014. Directory of Brazilian Livestock. 23th ed. Instituto FNP, São Paulo, SP, Brazil.

AOAC. 1998. Official Methods of Analysis. 16th ed. Association of Official Analytical Chemists. Arlington, VA, USA.

Arboitte, M. Z., I. L. Brondani, J. Restle, L. F. Silva, L. B. Pereira, and C. G. Santos. 2012. Carcass characteristics of small and medium-frame aberdeen angus young steers. Acta Sci. Anim. Sci. 34:49-56.

Berg, R. T. and L. E. Walters. 1983. The meat animal: Changes and challenges. J. Anim. Sci. 57:133-146.

CIOMS/OMS. 1985. Council for International Organizations of Medical Services. 1st ed. International Guiding Principles for Biomedical Research Involving Animals. ERIC Clearinghouse, Geneva, Switzerland.

Dian, P. H. M., I. N. Prado, M. V. Valero, P. P. Rotta, R. M. Prado, R. R. Silva, and L. M. A. Bertipaglia. 2010. Levels of replacing corn by cassava starch on performance and carcass characteristics of bulls finished in feedlot. Semina: Ci. Agrárias. 31:497-506.

Forbes, J. M. 1988. Metabolic aspects of the regulation of voluntary food intake and appetite. Nutr. Res. Rev. 1:145-168.

Hankins, O. G. and P. E. Howe. 1946. Estimation of the composition of beef carcasses and cuts. USDA Techn. Bull. 926:1-20.
Hocquette, J. F., S. Tesseraud, I. Cassar-Malek, Y. Chilliard, and I. Ortigues-Marty. 2007. Responses to nutrients in farm animals: Implications for production and quality. Animal 1:1297-1313.

Ito, R. H., I. N. Prado, J. V. Visentainer, R. M. Prado, C. A. Fugita, and M. C. O. Pires. 2010. Carcass characteristics, chemical and fatty acid composition of Longissimus muscle of Purunã bulls slaughtered at 18 or 24 months of age. Acta Sci. Anim. Sci. 32:299-307.

Ito, R. H., M. V. Valero, R. M. Prado, D. C. Rivaroli, D. Perotto, and I. N. Prado. 2012. Meat quality from four genetic groups of bulls slaughtered at 14 months old. Acta Sci. Anim. Sci. 34:425-432.

Kuss, F., J. López, J. Restle, J. O. J. Barcellos, J. L. Moletta, and M. C. P. Leite. 2010. Qualidade da carne de novilhos terminados em confinamento e abatidos aos 16 ou 26 meses de idade. R. Bras. Zootec. 39:924-931.

Lee, C. Y., D. M. Henricks, G. C. Skelley, and L. W. Grimes. 1990. Growth and hormonal response of intact and castrate male cattle to trenbolone acetate and estradiol. J. Anim. Sci. 68:2682-2689.

López-Campos, Ó., J. A. Basarab, V. S. Baron, J. L. Aalhus, and M. Juárez. 2012. Reduced age at slaughter in youthful beef cattle: Effects on carcass merit traits. Can. J. Anim. Sci. 92:449-463.

Lunstra, D. D., J. J. Ford, and S. E. Echternkamp. 1978. Puberty in beef bulls: hormone concentrations, growth, testicular development, sperm production and sexual aggressiveness in bulls of different breeds. J. Anim. Sci. 46:1054-1062.

Maggioni, D., J. A. Marques, P. P. Rotta, F. Zawadzki, R. H. Ito, and I. N. Prado. 2009. Feed intake. Semina: Ci. Agrárias. 30:963-974.

Maggioni, D., I. N. Prado, F. Zawadzki, M. V. Valero, J. A. Marques, A. M. Bridi, J. L. Moletta, and J. J. S. Abrahão. 2012 Grupos genéticos e graus de acabamento sobre qualidade da carne de bovinos. Semina: Ci. Agrárias. 33:391-402.

Mertens, D. R. 1994. Regulation of Forage Intake. 1 ed. Forage Quality, Evaluation, and Utilization. American Society of Agronomy, Madison, WI, USA.

Mertens, D. R. 2002. Gravimetric determination of amylasetreated neutral detergent fiber in feeds with refluxing in beakers or crucibles: Collaborative study. J. AOAC Int. 85:1217-1240.

NRC. 2000. Nutrient Requirements of Beef Cattle. 7th ed. Natl. Acad. Press, Washington, DC, USA.

Pacheco, P. S., J. Restle, J. H. S. Silva, I. L. Brondani, L. L. Pascoal, M. Z. Arboitte, and A. K. Freitas. 2005. Feedlot performance of steers and young steers of different genetic groups. R. Bras. Zootec. 34:963-975.

Pinto, A. P., W. G. Nascimento, J. J. S. Abrahão, D. Perotto, J. L. Moletta, and S. M. B. Lugão. 2009. Digestibility, intake, performance and carcass characteristics of young crossbred bulls in feedlot with cane or sorghum silage. R. Bras. Zootec. 38:2258-2263.

Prado, I. N., D. Maggioni, J. J. S. Abrahão, F. Zawadzki, M. V. Valero, J. A. Marques, R. H. Ito, and D. Perotto. 2011. Chemical composition and fatty acids profile on Longissimus muscle of crossbred bulls fed with sugar cane or sorghum silage and finished with 3.4 or $4.8 \mathrm{~mm}$ of fat thickness. Semina: Ci. Agrárias. 32:1461-1476. 
Prado, I. N., A. D. Pinheiro, C. R. Alcalde, L. M. Zeoula, W. G. Nascimento, and N. E. Souza. 2000. Substitution levels of corn by orange peel on performance and carcass traits of feedlot bulls. R. Bras. Zootec. 29:2135-2141.

Prado, I. N., R. M. Prado, P. P. Rotta, J. V. Visentainer, J. L. Moletta, and D. Perotto. 2008a. Carcass characteristics and chemical composition of the Longissimus muscle of crossbred bulls (Bos taurus indicus vs Bos taurus taurus) finished in feedlot. J. Anim. Feed Sci. 17:295-306.

Prado, I. N., P. P. Rotta, R. M. Prado, J. V. Visantainer, J. L. Moletta, and D. Perotto. 2008b. Carcass characteristics and chemical composition of the Longissimus muscle of Purunã and 1/2 Purunã vs. 1/2 Canchin bulls meat quality of bulls. Asian Australas. J. Anim. Sci. 21:1296-1302.
Rotta, P. P., R. M. Prado, I. N. Prado, M. V. Valero, J. V. Visentainer, and R. R. Silva. 2009. The effects of genetic groups, nutrition, finishing systems and gender of Brazilian cattle on carcass characteristics and beef composition and appearance: A review. Asian Australas. J. Anim. Sci. 22:17181734.

SAS. 2004. SAS/STAT User Guide, Version 9.1.2. SAS Institute Inc, Cary, NC, USA.

Silva, R. R., I. N. Prado, G. G. P. Carvalho, F. F. Silva, V. V. S. Almeida, H. A. Santana Júnior, M. L. Paixão, and G. Abreu Filho. 2010. Supplementation levels in finishing of Nellore steers on pastures: economic aspects. R. Bras. Zootec. 39:2091-2097.

Van Soest, P. J., J. B. Robertson, and B. A. Lewis. 1991. Methods for dietary fiber, neutral detergent fiber, and nonstarch polysaccharides in relation to animal nutrition. J. Dairy Sci. 74:3583-3597. 